\title{
Isolation and characterization of pigmented bacteria showing antimicrobial activity from Malaysian marine environment
}

\author{
Mahtab $\underline{\text { Jafarzade }}^{1^{*}}$, Nur Ain $\underline{\text { Yahya }}^{1}$, Suhaiza $\underline{\text { Mohamad }}^{1}$, Gires Usup ${ }^{2}$ and Asmat $\underline{\text { Ahmad }}^{1^{\star}}$ \\ ${ }^{1}$ School of Bioscience and Biotechnology, Faculty Science and Technology, Universiti Kebangsaan Malaysia, 43600 \\ Bangi, Selangor, Malaysia. \\ 2 School of Environmental and Natural Resources Laboratory, Universiti Kebangsaan Malaysia, 43600 Bangi, Selangor, \\ Malaysia. \\ Email: jafarzadem@yahoo.com and asmat@ukm.my
}

Received 31 August 2012; Received in revised form 8 October 2012; Accepted 2 November 2012

\begin{abstract}
Aims: Natural products play a prominent role in the discovery of leads for the development of drugs in the treatment of human diseases. Much of nature remains to be explored, especially marine and microbial environments.

Methodology and results: Fifty-five pigmented marine bacteria were isolated from sponges, seawater, mangrove sediment, sea cucumber and mussel from different coastal area of Malaysia. The antimicrobial activities of these bacteria were investigated by disk diffusion method against pathogenic bacteria. Out of 55 isolates, 18 isolates exhibited antimicrobial activity, which based on morphological characterization, 53\% of them were Gram positive and $47 \%$ were Gram negative. All active isolates were able to tolerate more than $4 \% \mathrm{NaCl}$ in the nutrient agar medium that indicated they were autochthonous to marine environment and moderate salt tolerant in nature. Molecular identification of isolates by the strong antimicrobial activities indicates that isolates WPRA3 (JX020764) and SM11-3j belong to genus Serratia and isolate SDPM1 (JQ083392) belongs to genus Zooshikella.
\end{abstract}

Conclusion, significance and impact of study: The results of present study revealed that the active isolates are potential producer of antimicrobial secondary metabolites and might be utilized as drug candidate.

Keywords: marine bacteria, pigmented bacteria, antimicrobial activity, secondary metabolite

\section{INTRODUCTION}

Oceans that cover three-quarters of the earth surface are the largest ecosystem in the world. Oceans may serve as the most essential and continuously sources to the discovery of novel microbes and their associated bioactive compounds. The tremendous environment in the ocean can be distributed on the basis of habitats which are at low temperatures (psychrophiles), high salinity (halophiles) and under high pressure (barophiles) (Soliev et al., 2011). These extreme marine environments can be stressful to resident organisms including microbes. Adaptation to these stress factors could involve metabolic changes in the production or secretion of chemical substances some of which could be bioactive. This could result into marine microbes being metabolically different in respect to their terrestrial counterparts.

Nowadays facing multiple drug resistant pathogenic microbes, such as methicillin-resistance Staphylococcus aureus (MRSA) and vancomycin-resistant Staphylococcus aureus (VRSA) is a serious issue. This has led to the investigation and discovery of novel antibiotic from time to time to overcome this problem. The diversity of marine organisms' species and the complex living circumstance surrounding these microbes have resulted into production of novel and unique secondary metabolite with much stronger bioactivities compared with terrestrial organisms (Carte, 1996; Rinehart, 2000; Schwartsmann et al., 2001). Hence, there has been an ongoing purposeful search for new potential drugs from the sea for more than two decades (Anand et al., 2006). However, in this study, the search for antimicrobial as drug candidate is still in the early stage, likewise screening for antimicrobial activity of marine bacteria around the coastal region of Malaysia. In order to screen for active substance, especially for new compounds, several research studies are currently oriented towards the isolation of new species especially from extreme marine habitats. As for this, in Malaysia, effort to obtain commercialized antibiotic substances, from laboratory to market product requires strong collaboration between researchers from different disciplines such as pharmacology, toxicology, biotechnology and chemistry.

Recently, microbial pigments have been proven to contain active compounds such as Streptomyces, an actinomycete that mainly produce red color in their 
colony. Pigment like prodigiosin (red), violacein (violet), and pyocianin (blue-green) are known to have active compounds such as anitimicrobial activity, antiviral, antitumor, antiprotozoa, antioxidant, anticancer and much more (Ferreira et al., 2004; Matz et al., 2004; Deorukhkar et al., 2007; Kim et al., 2010). It is crucial to pin-point the adherence of pigment in bacteria, which is for industrial applications. Pigmented marine natural products can contribute to a variety of applications, from health, cosmetic up to the flavours of food additives, paint industry, fabric dye, and ink manufacture, making it the interesting subject of this study.

The marine environment in Malaysia constitutes a large reservoir of untapped resources for the discovery of bioactive compounds. Malaysia is a maritime country with unique treasures such as the ecosystem of mangroves, mudflats, coral reefs, seaweeds, lagoons and estuaries. Unfortunately, there is less research done on the discovery of biological diversity in these area, particularly in marine bacteria. Owing to this, a study has been carried out to isolate and characterize potential marine bacteria from Malaysian marine environment with potential antimicrobial compounds.

\section{MATERIALS AND METHODS}

\section{Isolation of pigmented marine bacteria}

Bacterial strains were isolated from different species of marine sponges and sea cucumber from Tinggi Island, mussel from Sungai Merbok (Kedah), mangrove sediment from Morib Beach and Sungai Melayu (Johor), and seawater of Port Dickson and Tinggi Island. Collected samples were rinsed three times with sterile sea water in order to remove the non-attached bacteria. Ten grams of each sample was placed into $100 \mathrm{~mL}$ marine broth (MB; Difco, USA) in $250 \mathrm{~mL}$ Erlenmeyer flask. All flasks were then incubated on a rotary shaker at $200 \mathrm{rpm}$ for 24 hours at $28{ }^{\circ} \mathrm{C}$. A 10 -fold serial dilution of each flask was prepared while $100 \mu \mathrm{L}$ of each dilution was plated onto marine agar (MA; Difco, USA) and incubated at $28{ }^{\circ} \mathrm{C}$ for 7 days. Isolation of pigmented bacteria with different colony characteristics was carried out from third day onwards up to the seventh day. The isolated colonies were repeatedly streaked to obtain pure cultures and maintained on marine agar slant at $4{ }^{\circ} \mathrm{C}$ for further studies.

\section{Test microorganisms}

The following Gram positive bacteria Bacillus subtilis ATCC 11774, Staphylococcus aureus ATCC 11632 and methicillin-resistant Staphylococcus aureus (MRSA) and Gram negative bacteria (Aeromonas hydrophila Ctt6, Escherichia coli ATCC 10536, Pseudomonas aeruginosa ATCC 27853 and Vibrio parahaemolyticus), yeast Candida albicans and fungi Aspergillus fumigatus were used in this study. The strains were obtained from the Universiti Kebangsaan Malaysia microbial culture collection. They were maintained on nutrient agar (NA; Difco, USA) slants at $4{ }^{\circ} \mathrm{C}$.

\section{Antimicrobial activity}

\section{Preliminary screening of antimicrobial activity}

Primary screening of antimicrobial activity of all the pigmented bacteria were determined by disk diffusion method described by Bauer et al. (1966) with some modifications. In brief, except for SDPM1 isolate, $20 \mu \mathrm{L}$ of each isolated bacteria grown in MB for $24 \mathrm{~h}$ was inoculated into standard paper disk and placed onto Mueller Hinton Agar (MHA; Difco, USA) plates containing the following pathogenic microorganisms $B$. subtilis, $E$. coli and $C$. albicans. As for SDPM1, a single colony of an overnight culture in nutrient agar supplemented with $3 \%$ $\mathrm{NaCl}$ was inoculated onto standard paper disk and placed onto Mueller Hinton Agar (MHA; Difco, USA) plates containing pathogenic microorganisms, $B$. subtilis, $E$. coli and $C$. albicans. All the plates were incubated at 37 ${ }^{\circ} \mathrm{C}$ for $24 \mathrm{~h}$. The absence of growth around the disks indicated the sensitivity of the reference microorganisms. Secondary screening for antimicrobial activity was conducted for all positive isolates. All of the experiments were performed in triplicates.

\section{Preparation of crude extract}

In order to extract the bioactive compounds, $10 \mathrm{~mL}$ of 24 hours old culture of positive pigmented bacteria were prepared by incubating each bacterium into $50 \mathrm{~mL} \mathrm{MB}$ in $250 \mathrm{~mL}$ Erlenmeyer flask at $28^{\circ} \mathrm{C}$ in a rotary shaker $(150$ $\mathrm{rpm})$. Then, $10 \mathrm{~mL}$ of enriched culture were transferred as seed into other $250 \mathrm{~mL}$ Erlenmeyer flasks containing $100 \mathrm{~mL} \mathrm{MB}$ and incubated at $28^{\circ} \mathrm{C}$ in a rotary shaker (150 rpm) for three days. To isolate the bioactive metabolites, the cell masses were separated by centrifugation at $4,000 \mathrm{rpm}$ for $20 \mathrm{~min}$ and the supernatants were extracted with equal volume of ethyl acetate (EA). The solvent layers were collected and then evaporated in a rotary evaporator (Buchi rotavapor R-124) to obtain crude required for second antimicrobial screening.

In addition, because isolate SDPM1 exhibited greater inhibition zone when cultured in solid medium compared to that of from liquid medium, its bioactive compounds was harvested from the agar culture plate as described by Abraham (2004) with some modifications. Approximately $100 \mathrm{~mL}$ of nutrient agar was used in this study. In a single plate, the isolate SDPM1 was inoculated onto nutrient agar supplemented with $3 \% \mathrm{NaCl}$ and incubated for 6 days at $29^{\circ} \mathrm{C}$. The cells were then gently scraped off and washed with sterile seawater by centrifugation at 10,000 rpm for 15 min at $4{ }^{\circ} \mathrm{C}$. The cells pellet were fully mixed with $20 \mathrm{~mL} E A$, protected from direct light with aluminium foil until they were completely bleached. The cells were removed by centrifugation and the EA extract was then evaporated in a rotary evaporator (Buchi rotavapor R-124) 
to obtain crude extracts for using in second antimicrobial activity screening.

\section{Secondary screening of antimicrobial activity}

Antimicrobial activity assay of the extracts was done using the disk diffusion method performed on MHA according to Bauer et al. (1966). The sensitivity of the test microorganism species to the EA crude extracts of the isolates was determined by measuring the sizes of inhibitory zones on the agar surface around the disks. All of the experiments were performed in triplicates. The results are reported as the average of three experiments. All positive pigmented isolates were subjected to preliminary characterization.

\section{Morphological and physiological characterization of the positive pigmented isolates}

Morphological and physiological characterization of active isolates was determined according to Bergey's Manual using isolates' colony observation on MA. Colony morphology of active pigmented bacteria was noted and this was followed by Gram staining. Overnight pure cultures of isolates growing on MA were used for Gram staining. Motility in SIM medium was also tested. Respiratory enzyme tests include oxidase and catalase test were investigated using standard methods described by Kovacs (1956) and Vera and Power (1980) respectively. The NA plates supplemented with different amount of $\mathrm{NaCl}$ in the range of $1 \%$ to $11 \% \mathrm{NaCl}$ were used for salt tolerance assay.

\section{Molecular identification of isolates with strong antimicrobial activity}

Isolates which exhibited the strong antibacterial activity were chosen for molecular identification. PCR amplification of the 16S rRNA gene was performed using two oligonucleotide primers, forward 5'CTCCTACGGGAGGCAGCAG-3' and reverse 5'WATTACCGCGGCKGCTG-3'. The PCR programme was set using heat thermal minicycler (MJ Research, USA) as follows: initial denaturation was carried out for $5 \mathrm{~min}$ at 94 ${ }^{\circ} \mathrm{C}$. It was followed by 35 cycles of denaturation at $94{ }^{\circ} \mathrm{C}$ for $45 \mathrm{~s}$, annealing at $55^{\circ} \mathrm{C}$ for $45 \mathrm{~s}$ and extension at 72 ${ }^{\circ} \mathrm{C}$ for $1.5 \mathrm{~min}$ with a further $10 \mathrm{~min}$ extension at $72{ }^{\circ} \mathrm{C}$, using UniversAll ${ }^{\mathrm{TM}}$ tissue PCR kit. For SDPM1 and SMII$3 \mathrm{j}$ isolates, DNA amplification was performed using primer pair forward 5-'AGAGTTTGATCCTGGCTCAG-3' and reverse 5'-GGTTACCTTGTTACGACTT-3' (Thiel and Imhoff, 2003). The PCR programme was set using heat thermal minicycler (MJ Research, USA) as follows: $95^{\circ} \mathrm{C}$ for $2 \mathrm{~min}$ (initial denaturation), $50^{\circ} \mathrm{C}$ for $30 \mathrm{~s}$ (annealing), and $72^{\circ} \mathrm{C}$ for $45 \mathrm{~s}$ (DNA synthesis). This was followed by 22 cycles of $95^{\circ} \mathrm{C}$ for $30 \mathrm{~s}, 50{ }^{\circ} \mathrm{C}$ and $72{ }^{\circ} \mathrm{C}$ for $2 \mathrm{~min}$, with a further $10 \mathrm{~min}$ at $72{ }^{\circ} \mathrm{C}$ for final extension. All the PCR products were purified using QIAquick PCR purification kit (Qiagen, Germany) based on company instruction and were sent to FirstBase Laboratory for nucleotide sequencing.

\section{Sequence comparison and phylogenetic analysis}

Nucleotide sequences were analysed by using BioEdit Sequence Alignment Editor. The 16S rRNA gene sequences of the selected isolates were compared with available 16S rRNA gene sequences in the EMBL, GenBank and DDBJ databases using the BLASTn search facility at the National Center for Biotechnology Information (NCBI) (http://www.ncbi.nlm.nih.gov). The phylogenetic tree was constructed using the MEGA version 4.0.2 program (Tamura et al., 2007) for assignment of close relationships at species level.

\section{RESULTS}

\section{Isolation of pigmented marine bacteria}

A total of 55 pigmented bacteria were randomly isolated from sponge, seawater, mangrove sediment, sea cucumber and mussel around the coast of Malaysia which exhibited $41 \%$ of orange colony, $31 \%$ yellow, $11 \%$ red, $11 \%$ pink, $4 \%$ blue-green while $2 \%$ red and/or violet in colony (Figure 1)

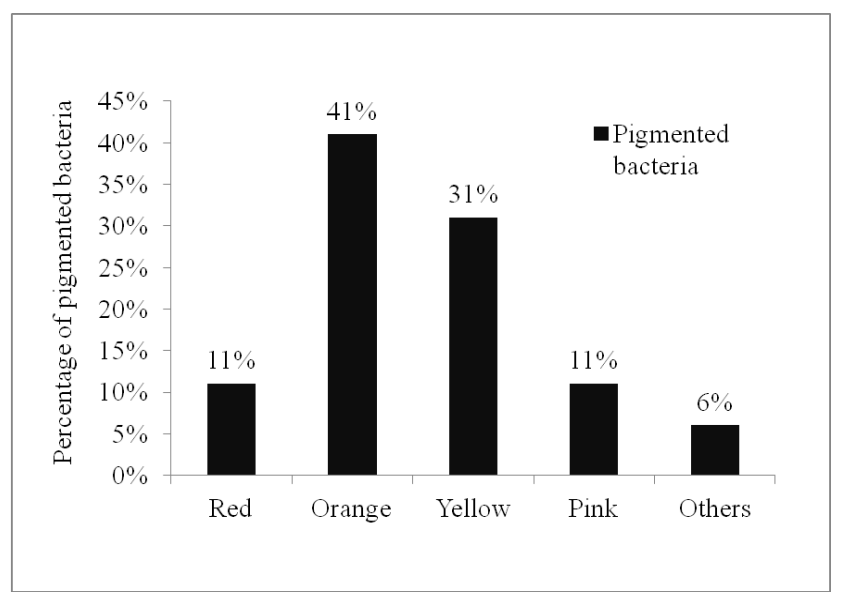

Figure 1: Percentage of the pigmented marine bacteria isolated from marine sources.

\section{Antimicrobial activity}

\section{Preliminary screening of antimicrobial activity}

Out of the 55 pigmented isolates subjected to preliminary screening for antimicrobial activity, 18 isolates exhibited antimicrobial activity against tested pathogens, that $52 \%$ against $E$. coli, $68 \%$ against $B$. subtilis and $37 \%$ against C. albicans (Table 1). From these positive antimicrobial isolates, $44 \%$ were isolated from six species of sponges, $22 \%$ from seawater, $22 \%$ from mangrove sediment, $6 \%$ sea cucumber and 6\% from mussel (Figure 2). 
Table 1: Primary screening for antimicrobial activity of marine pigmented bacteria.

\begin{tabular}{|c|c|c|c|}
\hline $\begin{array}{l}\text { Isolates/ } \\
\text { pathogens }\end{array}$ & BS & EC & $\mathrm{CA}$ \\
\hline SDPM1 & + & + & ++ \\
\hline WTG22 & ++ & - & ++ \\
\hline $\begin{array}{l}\text { SCTGRC } \\
\text { W }\end{array}$ & - & ++ & ++ \\
\hline SM11-3j & ++ & + & + \\
\hline SPTOD1 & - & +++ & +++ \\
\hline SPTYF & - & ++ & - \\
\hline SPTOF3 & ++ & ++ & - \\
\hline SPTYH4 & + & ++ & - \\
\hline SPTYI1 & + & - & - \\
\hline SPTYI2 & + & ++ & - \\
\hline SPTYJ1 & ++ & + & - \\
\hline SPTOL4 & - & + & ++ \\
\hline WPRA3 & +++ & - & - \\
\hline WPRB4 & ++ & - & - \\
\hline WPRB6 & - & - & ++ \\
\hline SDR1 & ++ & ++ & - \\
\hline SDGB2 & - & + & - \\
\hline SDON & +++ & - & ++ \\
\hline \multicolumn{4}{|c|}{$\begin{array}{l}+5.5-9.9 \mathrm{~mm} \\
++10.0-14.9 \mathrm{~mm} \\
+++>15.0 \mathrm{~mm}, \\
-: \text { no inhibition zone; BS: } \\
\text { CA: Candida albicans }\end{array}$} \\
\hline
\end{tabular}

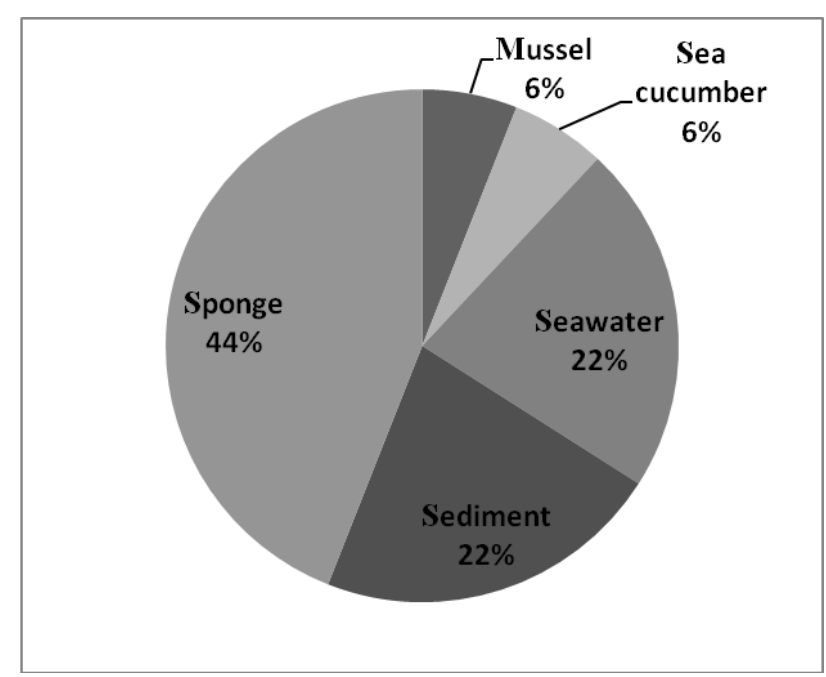

Figure 2: Percentage of the isolated pigmented bacteria with antimicrobial activity from different sources of marine environment.

\section{Secondary screening of antimicrobial activity}

A total of 9 test microbes were chosen for secondary screening of antimicrobial activity using EA extract of previous positive isolates. Of the 18 isolates, five isolates namely SDPM1, SM11-3j, SPTOD1, WPRA3 and WPRB4 exhibited antimicrobial activity against more than three test pathogenic microbes while eight isolates (SPTOF3, SPTYH4, SPTYI2, SPTYJ1, SPTOL4, SDR1, SDGB2 and SDON) showed activity against two test microbes. In addition, isolate SPTYF showed specific antimicrobial activity against $E$. coli, while SPTYI1 and WPRB6 specifically inhibited $B$. subtilis and $C$. albicans, respectively (Table 2). Remarkably, all of five isolates that exhibited higher antimicrobial activity were Gram negative. Example of crude extracts inhibitory effect of isolates WPRA3, SM11-3j and SDPM1 against $A$. fumigatus, $A$. hydrophila and $B$. subtilis are shown in Figure 3.

\section{Morphological and physiological characterization}

Out of the 18 active isolated bacteria, $44 \%$ were Gram negative and $56 \%$ were Gram positive. Colony morphology of active isolates such as colour and shape of colony was obtained on MA after $24 \mathrm{~h}$. The isolates SPTOD1, SPTOF3, SDON and SPTOL4 were orange in colony, SPTYF, SPTYH4, SPTYI1, SPTYI2 and SPTYJ1 were yellow, SM11-3j, WPRA3, WPRB4, SDR1 and WPRB6 were red, WTG22 was pink, SDGB2 was green while SDPM1 was red (with metallic green sheen) and/ or violet. Cell morphology of the isolates was obtained by microscopic observation. Isolates SPTOD1, WTG22 and SPTOF3 were coccobacilli, isolate SPTYF was coccus, isolate SPTOL4 was streptococcus and the rest were rod in shape. The results of motility and respiratory enzyme tests indicated that $61 \%$ of positive isolates were motile, $22 \%$ were oxidase positive and $94 \%$ were catalase positive. All active isolates were able to tolerate more than $4 \% \mathrm{NaCl}$ in the NA medium that indicated they were autochthonous to marine environment and moderate salt tolerance in nature. Result of morphological and physiological characterization of the isolates as shown in Table 3.

\section{Molecular characterization}

Isolates SDPM1, SM11-3j and WPRA3 which exhibited strong and broad spectrum antimicrobial activity were selected for molecular characterization. The size of PCR products was $\sim 1.5 \mathrm{~kb}$, which were detected with $1 \%$ agarose gel electrophoresis. The length of the partial $16 \mathrm{~S}$ rRNA gene sequence of the isolates SDPM1, SM11-3j and WPRA3 were $1301 \mathrm{bp}, 1445 \mathrm{bp}$ and $1477 \mathrm{bp}$ respectively. Comparative $16 \mathrm{~S}$ RRNA gene sequence analysis showed that the isolate WPRA3 (GenBank accession number JX020764) shared 97\% similarities with Serratia nematodiphila strain DZ0503SBS1 (EU914257) and Serratia marcescens subsp. sakuensi (AB061685), isolate SDPM1 (GenBank accession number 
Table 2: Secondary screening of antimicrobial activity from ethyl acetate crude extracts of marine pigmented bacteria.

\begin{tabular}{|c|c|c|c|c|c|c|c|c|c|}
\hline \multirow{2}{*}{$\begin{array}{l}\text { Pigmented } \\
\text { isolates }\end{array}$} & \multicolumn{8}{|c|}{ Inhibition zone (mm) } & \\
\hline & $\mathrm{EC}$ & PA & VP & $\mathrm{AH}$ & BS & SA & MRSA & $\mathrm{CA}$ & $\mathrm{AF}$ \\
\hline SDPM1 & - & - & 9 & - & 9 & 7.5 & 9 & 11.5 & - \\
\hline WTG22 & - & - & NT & - & 5.5 & - & - & - & NT \\
\hline SCTGRCW & - & - & NT & - & - & - & - & - & NT \\
\hline SM11-3j & - & NT & - & 51 & 35 & 15 & 20 & 30 & NT \\
\hline SPTOD1 & 30 & - & - & - & - & 14 & - & 28 & 10 \\
\hline SPTYF & 10 & - & - & - & - & - & - & - & - \\
\hline SPTOF3 & 14 & - & - & - & 10 & - & - & - & - \\
\hline SPTYH4 & 11 & - & - & - & 8 & - & - & - & - \\
\hline SPTYI1 & - & - & - & - & 8 & - & - & - & - \\
\hline SPTYI2 & 12 & - & - & - & 8 & - & - & - & - \\
\hline SPTYJ1 & 8 & - & - & - & 10 & - & - & - & - \\
\hline SPTOL4 & 8 & - & - & - & - & - & - & 10 & - \\
\hline WPRA3 & - & 15 & 35 & - & 45 & 25 & 30 & - & 32 \\
\hline WPRB4 & - & - & 20 & - & 10 & 10 & 10 & - & - \\
\hline WPRB6 & - & - & - & - & - & - & - & 12 & - \\
\hline SDR1 & 12 & - & - & - & 10 & - & - & - & - \\
\hline SDGB2 & 8 & - & - & 10 & - & - & - & - & - \\
\hline SDON & - & - & - & - & 15 & - & - & 10 & - \\
\hline
\end{tabular}

- : no inhibition zone

NT: not tested; EC: Escherichia coli; PA: Pseudomonas aeruginosa; VP: Vibrio parahaemolyticus; AH: Aeromonas hydrophila BS: Bacillus subtilis; SA: Staphylococcus aureus; MRSA: methicillin-resistant S. aureus; CA: Candida albicans; AF: Aspergillus fumigatus

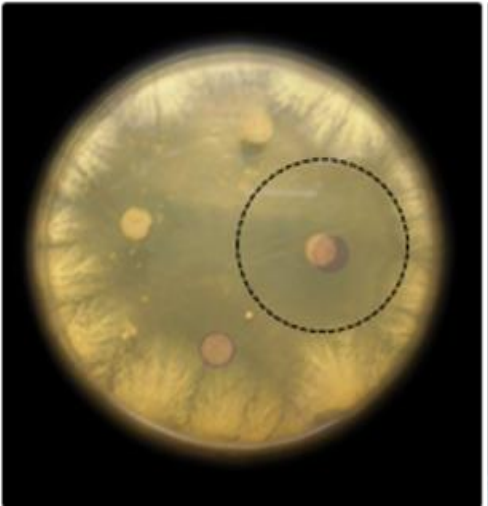

A

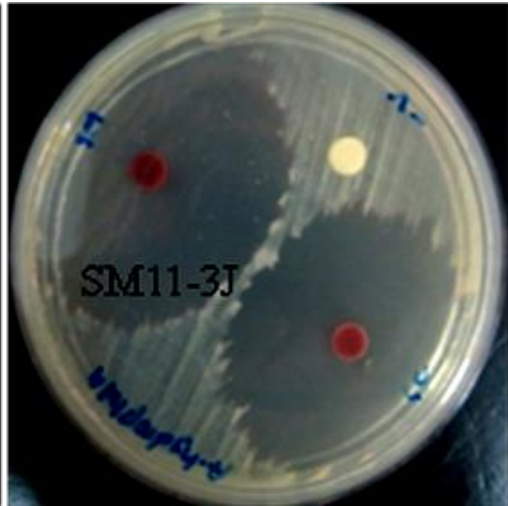

B

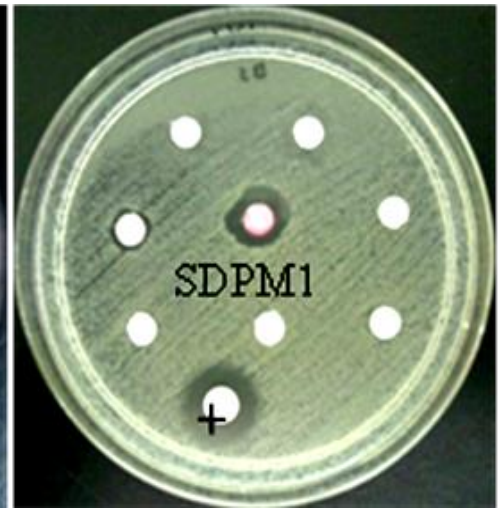

C

Figure 3: Ethyl acetate crude extracts inhibitory effect of the isolate WPRA3 against $A$. fumigatus (A), isolate SM11-3j against $A$. hydrophila (B) and isolate SDPM1 against $B$. subtilis (C). 
Table 3: Morphological and physiological characterization of the positive pigmented isolates.

\begin{tabular}{|c|c|c|c|c|c|c|c|c|c|}
\hline Isolates & Source & Origin & Gram & $\begin{array}{c}\text { Cell } \\
\text { morphology }\end{array}$ & Pigment & OX & CT & $\begin{array}{c}\% \\
\mathrm{NaCl}\end{array}$ & $M$ \\
\hline SDPM1 & Sediment & M.B & - & Rod & Red / violet & + & + & 6 & + \\
\hline WTG22 & Seawater & T.I & - & Coccobacillus & Pink & - & + & 6 & + \\
\hline SCTGRCW & $\begin{array}{c}\text { Sea } \\
\text { cucumber }\end{array}$ & T.I & - & Coccobacillus & Red & - & + & 6 & + \\
\hline SM11-3j & Mussels & S.M & - & Rod & Red & - & + & 6 & + \\
\hline SPTOD1 & Sponge & T.I & - & Coccobacillus & Orange & - & + & 8 & + \\
\hline SPTYF & Sponge & T.I & + & Coccus & Yellow & - & + & 6 & - \\
\hline SPTOF3 & Sponge & T.I & + & Coccobacillus & Orange & - & + & 10 & - \\
\hline SPTYH4 & Sponge & T.I & + & Rod & Yellow & - & + & 8 & - \\
\hline SPTYI1 & Sponge & T.I & + & Rod & Yellow & + & - & 8 & + \\
\hline SPTYI2 & Sponge & T.I & - & Rod & Yellow & - & + & 8 & - \\
\hline SPTYJ1 & Sponge & T.I & + & Rod & Yellow & - & + & 8 & + \\
\hline SPTOL4 & Sponge & T.I & + & Staphylococcus & Orange & + & + & 10 & + \\
\hline WPRA3 & Seawater & P.D & - & Rod & Red & - & + & 6 & + \\
\hline WPRB4 & Seawater & P.D & - & Rod & Red & - & + & 6 & + \\
\hline WPRB6 & Seawater & P.D & + & Rod & Red & - & + & 8 & + \\
\hline SDR1 & Sediment & S.M.J & + & Rod & Red & - & + & 6 & - \\
\hline SDGB2 & Sediment & S.M.J & + & Rod & Green & - & + & 4 & - \\
\hline SDON & Sediment & S.M.J & + & Rod & Orange & + & + & 4 & - \\
\hline
\end{tabular}

T.I: Tinggi Island; P.D: Port Dickson; S.M: Sungai Merbok, Kedah; M.B: Morib Beach; S.M.J: Sungai Melayu, Johor OX: oxidase; CT: catalase; M: motility

JQ083392) shared 98\% similarities with Zooshikella ganghwensis strain JC2044 (AY130994) and isolate SM11-3j shared 96\% similarities with Serratia nematodiphila strain DZ0503SBS1 (EU914257), Serratia marcescens subsp. sakuensi (AB061685) and Serratia marcescens subsp. marcescens ATCC 13880.

\section{Phylogenetic analysis}

Figure 4 shows the tree topology generated using the neighbour-joining method. There were two clades formed, clade 1 consists of the family Enterobacteriaceae and clade 2 consists of the family Hahellaceae with bootstrap values of 100 . There were two subclades in clade 1 , which are subclade $1 \mathrm{a}$ and subclade 1b. Subclade 1a with bootstrap value of 93 consists of the genus Serratia and form two clusters, while subclade $1 \mathrm{~b}$ consists of the genus
Enterobacter and Klebsiella. Clade 2 consists of two subclades, which are subclade $2 a$ and subclade $2 b$. Subclade 2 a consists of the genus Hahella while subclade $2 \mathrm{~b}$ consists of the genus Zooshikella with bootstrap values of 100 and form two clusters. Alteromonas macleodii strain DSM 6062 (Y18228) was selected as an outgroup.

\section{DISCUSSION}

Bacterial isolation led to variety of pigmented isolates, the most were orange in color, followed by yellow, red, pink, blue-green and violet. Pigmentation is widespread among bacteria and pigments found in marine heterotrophic bacteria consist of carotenoid, flexirubin, xanthomonadine, and prodigiosin (Kim et al., 2007). The carotenoids are considered to be the main and most 


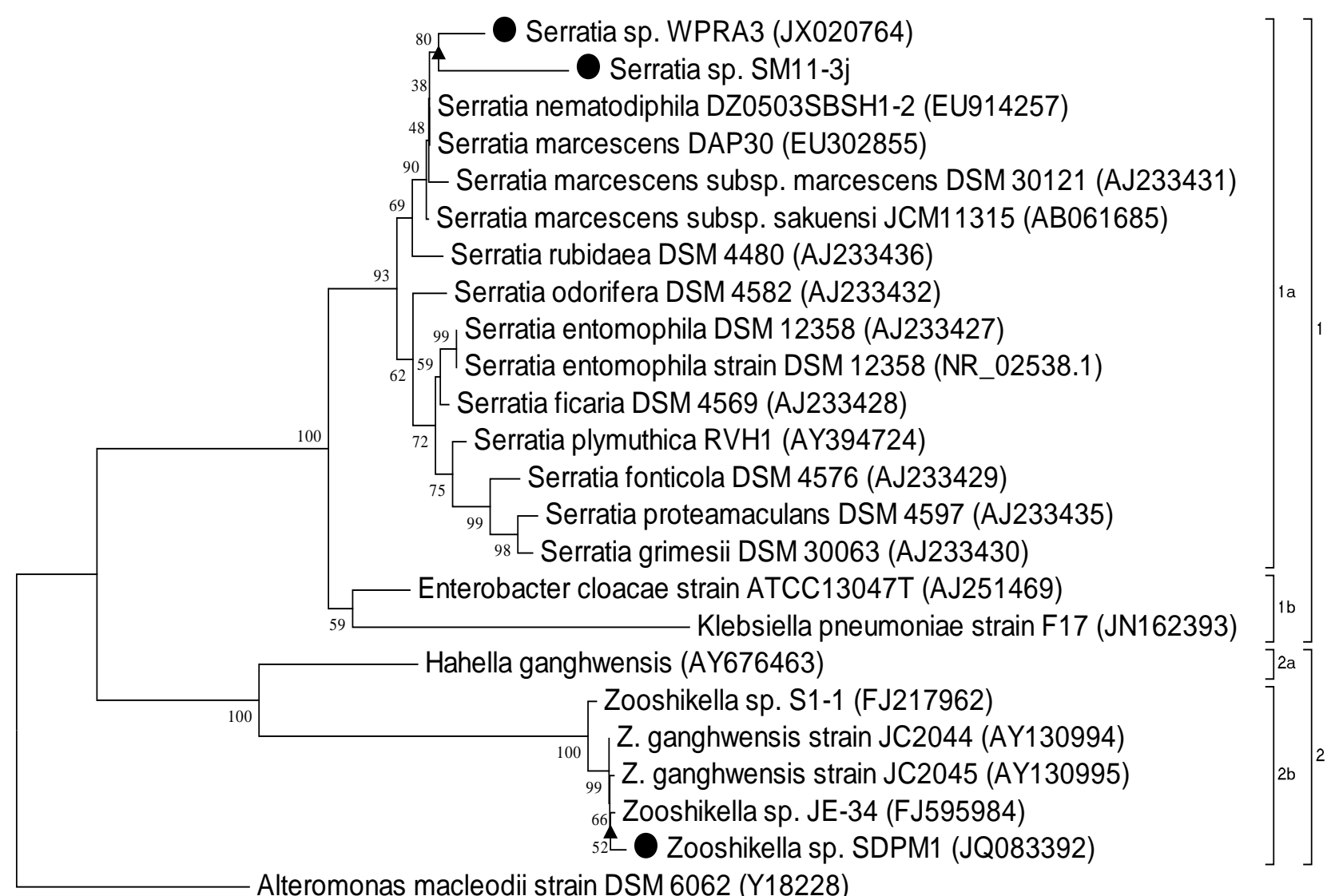

Alteromonas macleodii strain DSM 6062 (Y18228)

Figure 4: Phylogenetic relationship of Serratia sp. WPRA3 (JX020764), Serratia sp. SM11-3j and Zooshikella sp. SDPM1 (JQ083392) to related bacteria based on neighbour-joining tree analysis of 16S rRNA gene sequence data. Bootstrap values (expressed as percentage of 1000 replications) are shown at branch nodes. Bar, 0.02 substitutions per nucleotide position. Alteromonas macleodii strain DSM 6062 (Y18228) was selected as an outgroup.

plentiful pigment groups, which appear orange, yellow or red (Marit et al., 2010). Antimicrobial activity of marine bacteria is a renowned phenomenon and indicated in a number of studies (Lemos et al., 1985; Dopazo et al., 1988; McCarthy et al., 1994). Results showed that bacteria isolated from sponges exhibited the highest antimicrobial activity compared to other sources. Marine sponges are rich sources of natural compounds, which exhibit wide variety of biological activity (De Rosa et al., 2003). Hence, novel microorganisms with potential biological activity were isolated from marine sponges (Hentschel et al., 2001). Moreover, the numbers of bacteria associated with marine sponges are two or three times more than seawater because of the specific surface and internal environmental niche of sponges (Friedrich et al., 2001). In this study Gram negative isolates showed higher antimicrobial activity rather than Gram positive isolates. This could be ascribed to the cell wall differences between these bacteria. A Gram negative cell wall consists of lipopolysaccharide that can act as toxin to protect bacteria against predator (Barnett 1992). The component of lipopolysaccharide can also makes the cell wall impermeable to lipophilic solutes (Pandey et al., 2004), hence gives more protection in Gram negative bacteria. A Gram-positive bacteria cell wall has a thick layer of peptidoglycan and should more susceptible because not an effective permeability barrier (Barnett, 1992; Pandey et al., 2004). Our result also suggested that pigment could involve in antimicrobial activity of isolates. Isolates that produce red pigment have higher antimicrobial activity followed by orange, yellow and green. Pigment that produces by marine bacteria is one of the bioactive compounds that can be isolate. Marine bacteria like Streptomyces, Pseudomonas and Vibrio are able to produce indole derivatives (quinines and violacein) and alkaloids (prodiginines and tambajamines). The red pigmented prodigiosin compounds were first isolated from the ubiquitous bacteria which are Serratia marcescens 
and identified as secondary metabolites (Soliev et al., 2011). However, further research is suggested to confirm this hypothesis.

Based on 16S rRNA sequences, isolate WPRA3 displayed $97 \%$ homology while isolate SMII-3j displayed $96 \%$ homology with that of their nearest neighbours, Serratia nematodiphila DZ0503SBSH1 (EU914257) and Serratia marcescens subsp. sakuensi (AB061685) respectively. The isolate WPRA3 and SMII-3j were rod shaped bacteria and motile. They produced a colony on an agar plate in which the color was red. Grimont and Grimont (1991) reported that the three species of the genus Serratia, $S$. marcescens, $S$. rubidaea and $S$. plymuthica able to produce a reddish pigment called prodigiosin under specific conditions. Furthermore, both isolates, WPRA3 and SMII-3j were Gram negative bacteria and demonstrated oxidase negative and catalase positive, the basic characteristics of genus Serratia. The phylogenetic tree based on the 16S rRNA sequences as shown in Figure 4 indicates that both isolates, WPRA3 and SMII-3j have close relationship with the genus Serratia. These results suggested that isolates WPRA3 and SMII-3j can be classified in the genus Serratia. The isolate SDPM1 was rod shaped bacterium that demonstrated oxidase and catalase activities and produce red and/ or violet colony on an agar plate. Based on $16 \mathrm{~S}$ rRNA sequences, isolate SDPM1 shared $98 \%$ similarities with its nearest neighbours, Zooshikella ganghwensis strain JC2044 (AY130994). Although isolate SDPM1 showed close relationship to the genus Zooshikella sp. JE-34 (FJ595984) in the phylogenetic tree (Figure 4), this isolate was suggested as a member of a new species in the genus Zooshikella. This was mainly based on the pigment production which recently known that Zooshikella able to produce red and yellowish-red but not violet pigment (Yi et al., 2003; Lan et al., 2008; Kim et al., 2010). Further identification of SDPM1 isolate is undergoing in order to confirm this suggestion.

\section{CONCLUSION}

A total of 55 marine pigmented bacteria had been isolated and were deposited in the university's culture collection. 18 isolates having antimicrobial activities and five of them were strongly active against pathogens tested and were suggested as a potentially drug candidate. Marine environment in Malaysia have good potential to serve as a source for the discovery of natural product. The understanding of biological properties of microbial pigment from environment in Malaysia not only make us curious about the pigment but also think that pigmented bacteria can provide a good bioactive compound or therapy for the other pathogens. The study about these pigmented bacteria also can contribute to medical or industrial uses like as a colorant or drugs. Further isolation or characterization of this bioactive compound from these pigmented marine bacteria will proceed and investigate.

\section{ACKNOWLEDGEMENTS}

Special thanks to Nur Diana Mehat, Rahimi Abd. Hamid and students involved in environmental microbiology laboratory session 2007/2008 and 2008/2009 for assisting in the process of sampling and isolation of bacteria. This work was supported by Ministry of Science, Technology and Innovation Malaysia (MOSTI) through grant UKMOUP-BTK-15/2007 and UKM-OUP-KPB-33-169.

\section{REFERENCES}

Abraham, T. J. (2004). Antibacterial marine bacterium deter luminous vibriosis in shrimp larvae. NAGA, WorldFish Center Quarterly 27(3), 28-31.

Anand, T. P., Bhat, A. W., Shouche, T. S., Roy, U., Siddharth, J. and Sharma, S. P. (2006). Antibacterial activity of marine bacteria associated with sponges from the coast of South East India. Microbial Research 161, 252-262.

Barnett, M. (1992). Microbiology Laboratory Exercises: Complete Version. 2nd Edn. Brown Publishers, Dubuque: Wm. C. pp. 114.

Bauer, A. W., Kirby, W. M. M., Sherris, J. C. and Turck, M. (1966). Antibiotic susceptibility testing by a standardized single disk method. The American Journal of Clinical Pathology 36(3), 493-496.

Carte, B. K. (1996). Biochemical potential of marine natural products. Bioscience 46, 271-286.

Deorukhkar, A. A, Chander, R., Ghosh, S. B. and Sainis, K. B. (2007). Identification of a redpigmented bacterium producing a potent antitumor N-alkylated prodigiosin as Serratia marcescens. Research in Microbiology 158, 399404.

De Rosa, S., Mitova, M. and Tommonero, G. (2003). Marine bacteria associated with sponges as a sources of cyclic peptides. Biomolecular Engineering 20, 311-316.

Dopazo, C. P., Lemos, M. L., Lodeiros, C., Bolinches, J., Barja, J. and Toranzo, A. E. (1988). Inhibitory activity of antibiotic producing marine bacteria against fish pathogens. Journal of Applied Bacteriology 65, 97-101.

Ferreira, C. V., Bos, C. L., Versteeg, H. H., Justo, G. Z., Duran, N. and Peppelenbosch, M. P. (2004). Molecular mechanism of violacein-mediated human leukemia cell death. The American Society of Hematology 104, 1459-1464.

Friedrich, A. B., Fischer, I., Proksch, P., Hacker, J. and Hentschel, U. (2001). Temporal variation of the microbial community associated with the Mediterranean sponge Aplysina aerophoba. FEMS Microbiology Ecology 38, 105-113.

Grimont, F. and Grimont, P. A. D. (1991). The genus Serratia, Prokaryotes. In: The Prokaryotes. Balows, A., Trüper, H. G., Dworkin, M., Harder, W. and Schleifer, K. H. (eds.) $3^{\text {rd }}$ edn. SpringerVerlag, New York. pp. 2822-2848. 
Hentschel, U., Schmid, M., Wagner, M., Fieseler, L., Gerrium, C. and Hacker, J. (2001). Isolation and phylogenetic analysis of bacteria with antimicrobial activities from the Mediterranean sponge Aplysina aerophoba and Aplysina cavernicola. FEMS Microbiology Ecology 35, 305-312.

Kim, D., Lee, J. S., Park, Y. K., Kim, J. F., Jeong, H., Oh, T. K., Kim, B. S. and Lee, C. H. (2007). Biosynthesis of antibiotic prodiginines in the marine bacterium Hahella chejuensis KCTC 2396. Journal of Applied Microbiology 102(4), 937-944.

Kim, J. S., Harikrishnan, R., Kim, M. C., Balasundaram, C. and Heo, M. S. (2010). Dietary administration of Zooshikella sp. enhance the innate immune response and disease resistance of Paralichthys olivaceus against Sreptococcus iniae. Fish and Shellfish Immunology 29, 104-110.

Kovacs, N. (1956). Identification of Pseudomonas pyocyanea by the oxidase reaction. Nature, London. 178, 703.

Lan, W., Mo, L., Cai, C., Zhou, Y., Yao, J. and Li, H. (2008). Studies on culture condition of new marine bacterium Zooshikella sp. SY01. Front Chemical Engineering in China 2(4), 443-446.

Lemos, M. L., Toranzo, A. E. and Barja, J. L. (1985). Antibiotic activity of epiphytic bacteria isolated from intertidal seaweeds. Microbial Ecology 11, 149163.

Marit, H. S., Kjell, D. J., Geir, K. A., Svein, V., Trond, E. E. and Per, B. (2010). Isolation and characterization of marine pigmented bacteria from Norwegian Coastal waters and screening for carotenoids with UVA-Blue light absorbing properties. The Journal of Microbiology 48(1), 1623.

Matz, C., Deines, P., Boenigk, J., Arndt, H., Erberl, L., Kjelleberg, S. and Jurgens, K. (2004). Impact of violacein-producing bacteria on survival and feeding of bacterivorous nanoflagellates. Applied and Environmental Microbiology 70, 1593-1599.
McCarthy, S. A., Johnson, R. M. and Kakimoto, D. (1994). Characterization of an antibiotic produced by Alteromonas luteoviolacea Gauthier 1982, 85 isolated from Kinko Bay, Japan. Journal of Applied Bacteriology 77, 426-432.

Pandey B., Ghimire, P. and Agrawal, V. P. (2004). Studies on the antibacterial activity of the actinomycetes isolated from the Khumbu Region of Nepal. A paper presented in the International Conference and Great Himalayas: Climate, Health, Ecology, Management and Conservation, Kathmandu, January. pp. 12-15.

Rinehart, K. L. (2000). Antitumor compounds from tunicates. Medical Research Reviews 20, 1-27.

Schwartsmann, G., Rocha, A. B., Berlinck, R. G. S. and Jimeno, J. (2001). Marine organisms as a source of new anticancer agents. Lancet Oncology 2, 221-225.

Soliev, A. B., Hosokawa, K. and Enomoto, K. (2011). Bioactive pigments from marine bacteria: Applications and physiological roles. EvidenceBased Complementary and Alternative Medicine Doi: 10.1155/2011/670349.

Tamura, K., Dudley, J., Nei, M. and Kumar, S. (2007). MEGA4: Molecular Evolutionary Genetics Analysis (MEGA) Software Version 4.0. Molecular Biology and Evolution 24(8), 1596-1599.

Thiel, V. and Imhoff, J. F. (2003). Phylogenetic identification of bacteria with antimicrobial activities isolated from Mediterranean sponges. Biomolecular Engineering 20, 421-423.

Vera, H. D. and Power, D. A. (1980). Sucrose broth. In: Manual of Clinical Microbiology. $3^{\text {rd }}$ Edn. Lemette, E. H. (eds.). American Society of Microbiology, Washington DC. pp. 998.

Yi, H., Chang, Y. H., Oh, H. W., Bae, K. S. and Chun, J. (2003). Zooshikella ganghwensis gen. nov., sp. nov., isolated from tidal flat sediments. International Journal of Systematic and Evolutionary Microbiology 53(4), 1013-1018. 